\title{
METODY
}

\section{AUTOMATYZAJCA W PROCESIE DETEKCJI OBIEKTÓW ARCHEOLOGICZNYCH Z DANYCH ALS}

\section{AUTOMATION IN THE PROCESS OF ARCHAEOLOGICAL OBJECTS DETECTION OF FROM ALS DATA}

\author{
Krzysztof Bakuła \\ Wydział Geodezji i Kartografii, Politechnika Warszawska \\ Zakład Fotogrametrii, Teledetekcji i Systemów Informacji Przestrzennej \\ pl. Politechniki 1, 00-661 Warszawa, Poland \\ Wojciech Ostrowski \\ Wydział Geodezji i Kartografii, Politechnika Warszawska \\ Zakład Fotogrametrii, Teledetekcji i Systemów Informacji Przestrzennej \\ pl. Politechniki 1, 00-661 Warszawa, Poland

\section{Rafat Zaptata} \\ Wydział Nauk Historycznych i Społecznych, Uniwersytet Kardynała Stefana Wyszyńskiego \\ w Warszawie \\ Instytut Historii Sztuki, Zakład Konserwacji Zabytków i Ochrony Krajobrazu \\ ul. Wóycickiego 1/3, bud. 23, 01-938 Warszawa, Poland
}

\begin{abstract}
In this paper approaches of historical, archaeological object detection from airborne laser scanning (hereinafter referred to as ASL) data were shown. Presented approach of automatic extraction of potential charcoal pile was the analysis of a selected processing of digital terrain model. In this example, it was attempted to detect archaeological sites on a small test area by usage of template matching. Positive results have proved a great number of detected objects. Methodology applied in the research allowed for finding of a large percentage of measured objects indirectly. Presented approach was also assessed by the results of object extraction in respect to field measurements in the area of interest, as well as effectiveness of automation procedure.
\end{abstract}




\section{WPROWADZENIE}

Celem artykułu jest prezentacja i omówienie procedury automatycznej detekcji obiektów archeologicznych na podstawie danych pochodzących z lotniczego skanowania laserowego. Praca ma również na celu ukazanie i ocenę skuteczności proponowanego rozwiązania, w odniesieniu do konkretnych obiektów zabytkowych - mielerzy z okolic Seredzic, związanych ze Staropolskim Okręgiem Przemysłowym. Lotnicze skanowanie laserowe (akronim ALS - ang. Airborne Laser Scanning) stanowi znakomite i nieinwazyjne narzędzie w zakresie rozpoznawania zasobów dziedzictwa kulturowego, zyskując w ostatnich latach coraz większe uznanie w środowiskach naukowo-badawczych i konserwatorskich. ALS to technologia skanowania laserowego, polegająca na pomiarze czasu powrotu promienia laserowego - wiązki światła, a następnie określeniu odległości między sensorem a innymi obiektami w przestrzeni. Na podstawie bardzo precyzyjnie obliczonej chwilowej pozycji aparatury rejestrującej jest określana pozycja skanowanych obiektów z bardzo dużą (sięgającą centymetrów) dokładnością ${ }^{1}$. Współczesne skanery laserowe umożliwiają wykonywanie setek tysięcy pomiarów na sekundę, dając podstawy do generowania danych dla dużych obszarów, sięgających tysięcy kilometrów kwadratowych. Zaletą omawianej metody jest przede wszystkim nieinwazyjność, szybkość oraz dokładność, które w połączeniu z innymi technikami teledetekcyjnymi stanowią zastaw narzędziowy współczesnych badań dziedzictwa archeologicznego. Zasadniczą zaletą lotniczego skanowania laserowego jest dokładny pomiar przestrzenny, umożliwiający trójwymiarową rejestrację powierzchni terenu, zwłaszcza na obszarach zalesionych.

Dotychczasowe wyniki zastosowania ALS-u potwierdzają użyteczność i skuteczność tej metody nieinwazyjnego rozpoznawania i inwentaryzowania zabytków na terenach obszarów leśnych ${ }^{2}$. Dane uzyskiwane w ramach ALS-u to nieoceniony potencjał badawczy, pozwalający obecnie na przeprowadzenie prospekcji terenowej na obszarach, które dotychczas nie doczekały się szerszych badań. Lotnicze skanowanie laserowe stosowane $\mathrm{w}$ archeologii stanowi narzędzie umożliwiające detekcję zabytków na obszarach leśnych, a więc tych, które do tej pory pozostawały poza zasięgiem rozpoznania obiektów zabytkowych za pomocą tradycyjnych, nieinwazyjnych metod poszukiwawczych (np. badań powierzchniowych, badań geofizycznych czy fotografii lotnicza). Metoda skanowania laserowego może być również stosowana na obszarach otwartych, co umożliwia rozpoznanie oraz dodatkową weryfikację obiektów zabytkowych. ALS jest przede wszystkim wykorzystany na tere-

\footnotetext{
${ }^{1}$ Kurczyński 2006; Wężyk 2006; Będkowski, Wężyk 2010; Marmol U., Lotniczy skaning laserowy. Postawy [prezentacja on-line] - http://geomatyka.lasy.gov.pl/c/document_library/get_file?uuid=117d470c -b48f-4592-bcc3-d16fd2bc5383\&groupId=107840

${ }^{2}$ Bewley, Crutchley, Shell 2005; Budziszewski, Zapłata 2011, LIDAR - nowe możliwości ochrony zabytków pradziejowego górnictwa krzemienia [referat] - konferencja „Konserwacja zapobiegawcza środowiska", 24 października 2011 r., Warszawa [wersja elektroniczna w archiwum UKSW]; Ludemann 2011.
} 
nach zalesionych czy też pokrytych szatą roślinną, a więc w warunkach uniemożliwiających typową obserwację terenu. Głównymi argumentami na rzecz zastosowania ALS-u w poszukiwaniach obiektów archeologicznych są:

- możliwość nieinwazyjnej prospekcji terenów leśnych,

- nieinwazyjność i znaczna niezależność od warunków pogodowych oraz pory dnia,

- bardzo wysoka dokładność wysokościowa danych uzyskiwanych nieinwazyjnie dla dużych obszarów,

- znaczący stan pokrycia kraju pomiarami - danymi, który niedługo stanowić będzie całość powierzchni kraju (dane ISOK - „Informatyczny System Osłony Kraju przed nadzwyczajnymi zagrożeniami”') ${ }^{3}$.

Rozpatrując wykorzystanie danych ALS w archeologii, należy również odnieść się do zagadnienia prezentacji danych w formie NMT (Numerycznego Modelu Terenu) oraz jego przetworzeń. W większości istniejących metod prezentacji danych wysokościowych wykorzystuje się modele pochodne od NMT, zaadaptowane do celów prospekcji archeologicznej lub specjalnie na jej potrzeby opracowane. Techniki te wykorzystywane są zarówno w przypadku manualnej prospekcji na ekranie czy wydruku, gdzie wynik takich badań zależy od doboru metod prezentacji ${ }^{4}$ oraz interpretacji, jak i w przypadku automatycznej detekcji, gdzie wykorzystywane są jako modele wejściowe ${ }^{5}$.

Automatyzację $\mathrm{w}$ procesie detekcji należy rozumieć jako procedurę nadzorowanego wyszukiwania i wskazywania za pomocą narzędzi geoinfromatycznych potencjalnych obiektów o podobnych cechach, takich jak kształt czy wielkość. Podstawą procesu automatycznej detekcji obiektów zabytkowych dla prowadzonych prac jest znajomość obiektów archeologicznych, zwłaszcza ich cech, np. owalność czy średnica. Na tej podstawie w następnej kolejności analizowany jest wygenerowany wcześniej NMT na bazie danych ALS, w celu wykrycia potencjalnych obiektów o wskazanych lub zbliżonych cechach. Rezultaty automatycznej detekcji na kolejnym etapie są interpretowane i weryfikowane $\mathrm{z}$ wynikami innych metod, w tym pochodzącymi z prospekcji terenowej czy lotniczej.

Najbardziej rozpowszechnioną techniką ukazywania rzeźby terenu, ale uważaną również za jedną z najsłabszych metod prezentacji, jest cieniowanie zboczy (ang. hillshading, shaded relief $)^{6}$ (ryc. 1a). Kokalij et al. wskazują, że podstawową zaletą tej techniki jest łatwość interpretacji ${ }^{7}$. To specyficzny rodzaj przetwarzania danych wysokościowych danego obszaru do obrazu prezentującego miejsca (powierzchnie) znajdujące się w cieniu, co jest rezultatem symulacji, w której wybrany teren oświe-

\footnotetext{
${ }^{3}$ http://www.gugik.gov.pl/projekty/isok

${ }^{4}$ Bennett, Welham, Hill, Ford 2012.

${ }^{5}$ Possel, Lindenbergh, Storms 2010.

${ }^{6}$ Štular, Kokalj, Oštir, Nuninger 2012.

${ }^{7}$ Kokalij, Zaksek, Oštir 2013.
} 
tlany jest równoległą wiązką światła ze źródła o podanym azymucie, kącie padania promieni i wysokości. Istotnym problemem zastosowania tej metody jest nieczytelność elementów liniowych, równoległych do wiązki światła. Trudność tę można rozwiązać, generując kilka takich modeli, umożliwiających stosowanie tzw. wielokierunkowego cieniowania zboczy (ang. hill-shading from multiple directions), a następnie tworząc z nich kompozycję barwną (ryc. 1c) lub wykorzystując analizę składowych głównych (ang. Principal Component Analysis - PCA) (ryc. 1e), którą zaproponowali Devereux et al. ${ }^{8}$. Ta ostatnia, jako najbardziej zaawansowana technika, polega na wygenerowaniu składowych głównych dla NMT oświetlonego z 16 równomiernie rozmieszczonych kierunków. W analizie takiej wykorzystanie pierwszych trzech składowych głównych umożliwia osiągnięcie dobrych wyników w przypadku interpretacji manualnej. Ważny jest również trzeci raster wynikowy składowych

a)

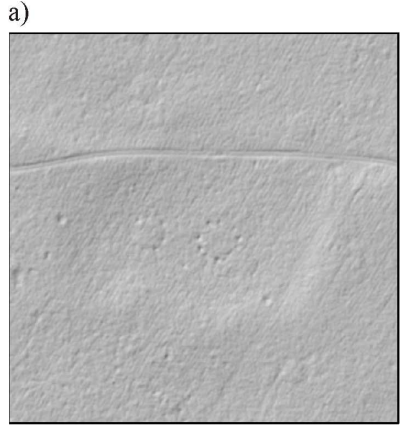

d)

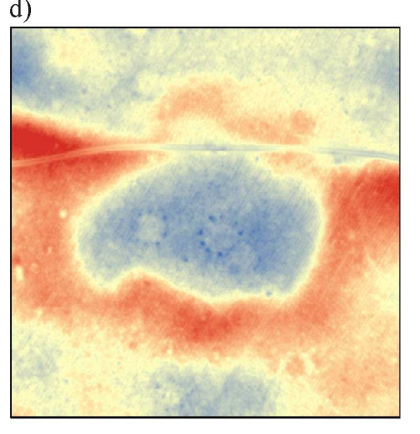

b)

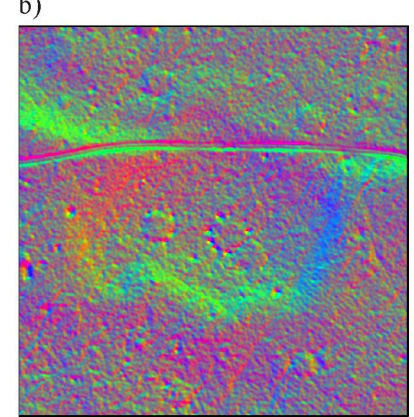

e)

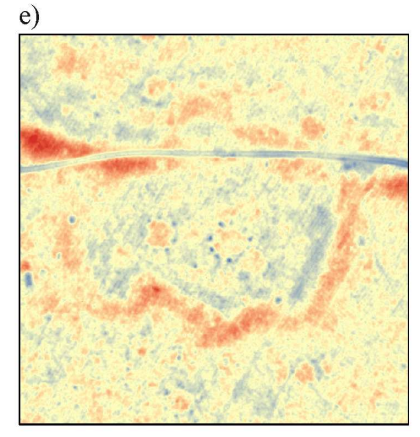

c)

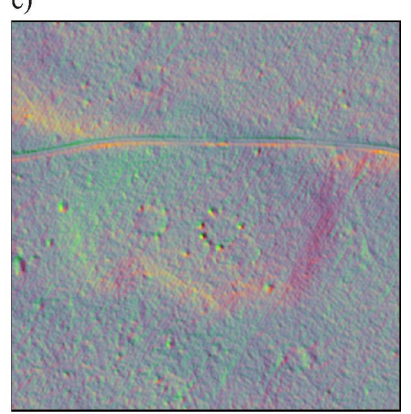

f)

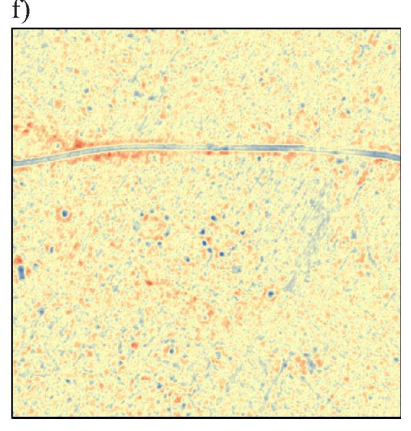

Ryc. 1. Produkty przetworzenia NMT: (a) model cieniowany, (b) kompozycja barwna z trzech modeli cieniowanych, (c) kompozycja barwna ze składowych głównych, raster Local Relief Model, obliczony z wykorzystaniem maski o promieniu: (d) $50 \mathrm{~m}$, (e) $10 \mathrm{~m}$, (f) $3 \mathrm{~m}$ (źródło danych: UKSW)

Fig. 1. Products of DTM processing: (a) hillshade model, (b) composition of 3 hillshade models, composition of principal components (c), raster of Local Relief Model created by different mask radius: (d) $50 \mathrm{~m}$, (e) $10 \mathrm{~m}$, (f) $3 \mathrm{~m}$ (data source: UKSW)

\footnotetext{
${ }^{8}$ Devereux, Amable, Crow 2013.
} 
głównych, ponieważ to na nim najlepiej jest widoczna mikrorzeźba. Metoda ta nie jest jednak pozbawiona wad, przez co nie należy do najczęściej wykorzystywanych ${ }^{9}$. Pierwszym jej problemem jest przesunięcie obiektów ${ }^{10}$, co ogranicza potencjał wykorzystania tej techniki w badaniach. Drugim mankamentem jest nieintuicyjny wygląd kompozycji barwnych ${ }^{11}$. Przykładem bardziej złożonego przekształcenia NMT dla detekcji obiektów archeologicznych jest indeks pozycji topograficznej (ang. Topographic Position Index - TPI) ${ }^{12}$. Należy on do grupy metod usuwających trend (ang. Trend Removal) ${ }^{13}$, polegających na stworzeniu modelu różnicowego pomiędzy szczegółowym NMT i jego uogólnieniem, co ma na celu wyeksponowanie lokalnie występujących deniwelacji terenu. Najprostszą metodą tworzenia takich modeli jest zastosowanie filtru uśredniającego (dolnoprzepustowego), a następnie odjęcie takiego przetworzonego NMT od modelu wejściowego ${ }^{14}$. Innym przykładem bardziej złożonego przekształcenia NMT jest lokalny model rzeźby terenu (ang. Local Relief Model - LRM). Technika ta, przedstawiona na potrzeby badań archeologicznych m.in. przez R. Hesse ${ }^{15}$, jako narzędzie służące wyodrębnieniu małych zmian w rzeźbie terenu podobnie jak TPI bazuje na odjęciu od wejściowego NMT jego uśrednienia. Wyznaczenie uogólnionego NMT filtrem dolnoprzepustowym nie usuwa jednak małych obiektów, stąd też w technice tej przyjęto metodę obliczania „oczyszczonego" (ang. purged) - uśrednionego NMT, co odróżnia LRM od innych metod usuwających trend. Modyfikacja ta polega na tym, że ze standardowego modelu różnicowego ekstrahowane są izolinie o zerowej wartości, następnie interpolowana jest ich wysokość z wejściowego NMT. Z tak powstałych linii wyznaczany jest następnie nowy „oczyszczony” NMT, który jest odejmowany od bazowego. Wartości LRM są silnie uzależnione od promienia, w którym wyznaczony jest uśredniony NMT (ryc. 1b, 1d, 1f). Możliwość pokazywania mikrotopografii dla terenów płaskich (bez znacznego zróżnicowania wysokości) oraz zachowywanie rzeczywistej skali (jednostki) obiektów sprawiają, że technika ta jest obecnie uznawana za najlepszą ${ }^{16}$.

\section{OPIS POSZUKIWANYCH OBIEKTÓW ZABYTKOWYCH}

W wyniku przeprowadzonych badań nieinwazyjnych w 2012 i 2013 r., opartych na prospekcji powierzchniowej, kwerendach archiwalnych oraz wstępnych analizach

\footnotetext{
${ }^{9}$ Štular, Kokalj, Oštir, Nuninger 2012.

${ }^{10}$ Bennett, Welham, Hill, Ford 2012.

${ }^{11}$ Kokalij, Zaksek, Ostir 2013.

${ }^{12}$ Weiss 2001

${ }^{13}$ Kokalij, Zaksek, Oštir 2013.

${ }^{14}$ Doneus, Briese 2006.

${ }^{15}$ Hesse 2010.

${ }^{16}$ Štular, Kokalj, Oštir, Nuninger 2012.
} 
danych, pochodzących $\mathrm{z}$ lotniczego skanowania laserowego $\mathrm{w}$ ramach realizacji projektu pt. ,Zastosowanie skaningu laserowego oraz teledetekcji w ochronie, badaniu i inwentaryzacji dziedzictwa kulturowego. Opracowanie nieinwazyjnych, cyfrowych metod dokumentacji i rozpoznawania zasobów dziedzictwa architektonicznego i archeologicznego", dokonano rozpoznania ponad 1000 mielerzy, które są pozostałością obiektów związanych z procesem pozyskiwania surowca energetycznego w przeszłości. Zespół zabytkowych mielerzy zlokalizowany został w okolicy miejscowości Seredzice w województwie mazowieckim, powiat radomski, gmina Iłża, na terenie Nadleśnictwa Marcule oraz Nadleśnictwa Polany (Regionalna Dyrekcja Lasów Państwowych w Radomiu) ${ }^{17}$. Badany obszar wchodzi w zakres Przedgórza Iłżeckiego, częściowo obejmując dolinę Iłżanki (część zachodnia całego kompleksu leśnego - okolice Krzewy i Seredzic-Zawodzia). Obszar leśny, na którym występują omawiane obiekty, to przede wszystkim las iglasty, w nieznacznym stopniu mieszany. Dominującym gatunkiem jest tu sosna zwyczajna/pospolita (Pinus sylvestris $L$.).

Chronologię zidentyfikowanych obiektów określono na podstawie datowania względnego, które oparto m.in. na materiałach historycznych oraz występujących na powierzchni obiektów (wrośniętych w ich strukturę) drzew, których wiek po ścięciu określono na ok. 100 lat. Literatura przedmiotu ${ }^{18}$ wskazuje, że rozpatrywane skupisko obiektów należy wiązać najprawdopodobniej z funkcjonującym na tych terenach Staropolskim Okręgiem Przemysłowym. Jest to najstarszy w Polsce zespół ośrodków przemysłowych, które funkcjonowały w dorzeczu rzeki Kamiennej, w obrębie Gór Świętokrzyskich, Płaskowyżu Suchedniowskiego, Garbu Gielniowskiego i Przedgórza Iłżeckiego, w województwach: świętokrzyskim, mazowieckim, łódzkim. Wymieniony wyżej ośrodek rozwijał się od XV do połowy XIX w., i był największym producentem żelaza na ziemiach polskich ${ }^{19}$. Niewykluczone jest również identyfikowanie obiektów $\mathrm{z}$ pradziejową (przedprzemysłową) produkcją węgla drzewnego i innych produktów przetwórstwa drewna, co jednak wymaga dalszych badań w zakresie określania bezwzględnej chronologii omawianych obiektów.

Mielerze to owalne obiekty, z dookolnymi zagłębieniami, które umożliwiały na bazie nieskomplikowanego, ale czasochłonnego procesu pozyskanie surowca energetycznego (węgla drzewnego) w oparciu o lokalne zasoby naturalne (drewno). W celu wyprodukowania węgla drzewnego układano w formie półowalnej kopuły drewno, które następnie przykrywano ziemią, gliną czy darnią (ryc. 2). Średnica takich obiektów wynosiła zazwyczaj od ok. kilku do kilkunastu metrów, dochodząc do wysokości ok. 3 m. Proces wypału węgla drzewnego trwał zazwyczaj kilka dni.

\footnotetext{
${ }^{17}$ Zapłata 2013.

${ }^{18}$ Bartosik 1979; Bielenin 1959; Kałagate, Osypiński, Stachowiak 2012; Rösler, Bönisch et al. 2012; Zientara 1954.

${ }^{19}$ Pazdur 1962a; Pazdur 1962b; Zieliński 1965; Guldon 2001; Guldon, Kaczor 1994; Łoboda 2001.
} 


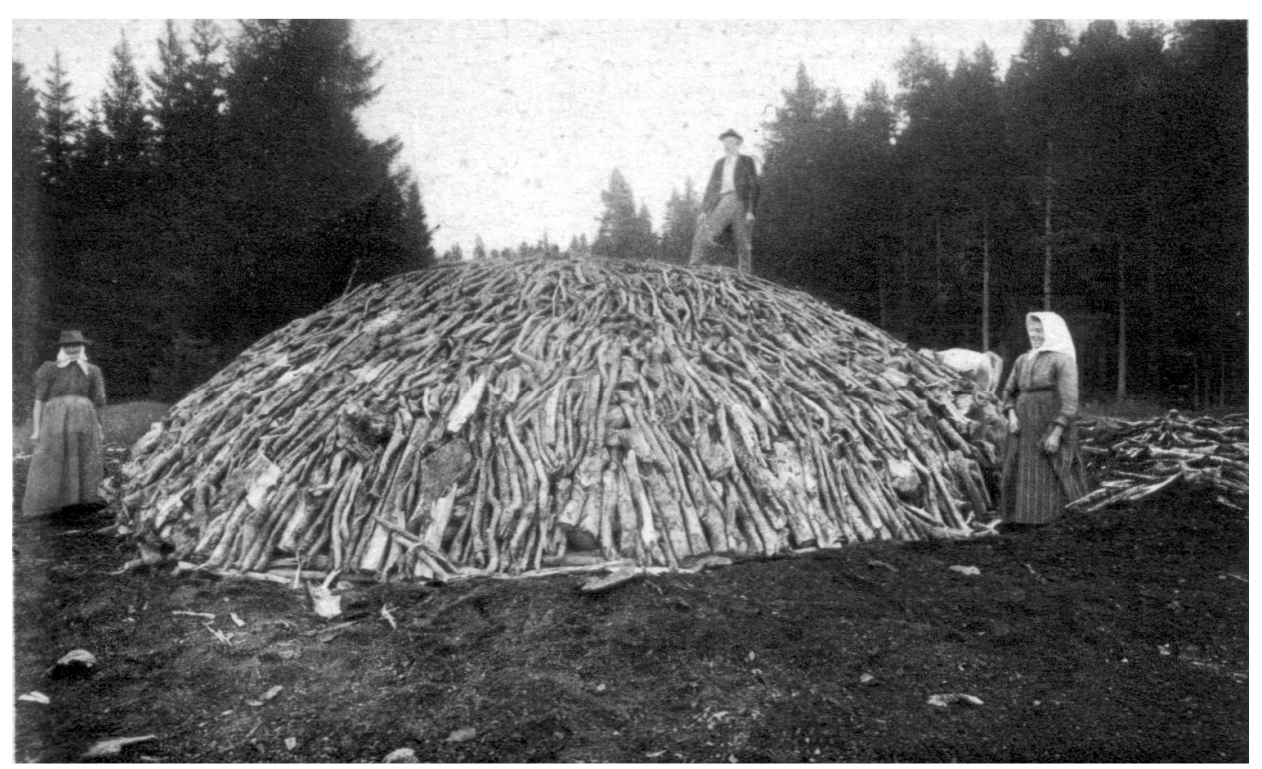

Ryc. 2. Przykładowy mielerz przed zasypaniem i wypałem (źródło: wikipedia.org http://pl.wikipedia.org/wiki/Plik:Charcoal_pile_05.jpg)

Fig. 2. The example of Charcoal pile before backfilling and firing (source: wikipedia.org http://pl.wikipedia.org/wiki/Plik:Charcoal_pile_05.jpg)

Po jego zakończeniu nakrycie kopuły usuwano, a wyprodukowany surowiec wybierano i transportowano z miejsc produkcji. Pozostałość, jak można wnioskować na podstawie badań wykopaliskowych, archiwalnych materiałów na temat produkcji ${ }^{20}$ czy archiwalnej fotografii, stanowiła warstwa popiołu z licznymi, drobnymi fragmentami węgla drzewnego. Obecnie uchwytne pozostałości to szczątkowo zachowane w wyniku procesów podpepozycyjnych dookolne zagłębienia, nieznaczne wypiętrzenie części centralnej obiektu czy też odsłonięte i zalegające na powierzchni terenu resztki stosu po wypale, o charakterystycznej ciemnej barwie, która umożliwia obecnie detekcję tych obiektów na terenach odsłoniętych (np. rolniczych) również dzięki prospekcji powierzchniowej i lotniczej ${ }^{21}$. Możliwe do zaobserwowania deniwelacje terenu związane $\mathrm{z}$ tymi obiektami sięgają często jedynie kilkunastu centymetrów, co powoduje, że obiekty te są trudne do zidentyfikowania w terenie, zwłaszcza na obszarach zalesionych czy porośniętych niską i średnią roślinnością (ryc. 3).

Na podstawie literatury przedmiotu, a także uwzględniając wyniki dotychczasowych badań, należy wnioskować, że omawiane obiekty w okresie funkcjonowa-

\footnotetext{
${ }^{20}$ Wybrane materiały źródłowe: Dunin 1928; Łabęcki 1841.

${ }^{21}$ Zapłata 2013.
} 
nia historycznego, jak również pradziejowego hutnictwa były bardzo powszechną i licznie występującą formą produkowania surowca energetycznego. W związku z tym wydaje się wskazane wypracowanie metodyki nieinwazyjnego, a zarazem szybkiego analizowania dużych obszarów, w celu wykrycia pozostałości tego typu obiektów. Jedną z możliwości rozpoznania tego zasobu zabytkowego jest włączenie do badań opracowanej metodyki, która opiera się również na wprowadzeniu elementów automatyzacji w procesie detekcji omawianych obiektów archeologicznych.
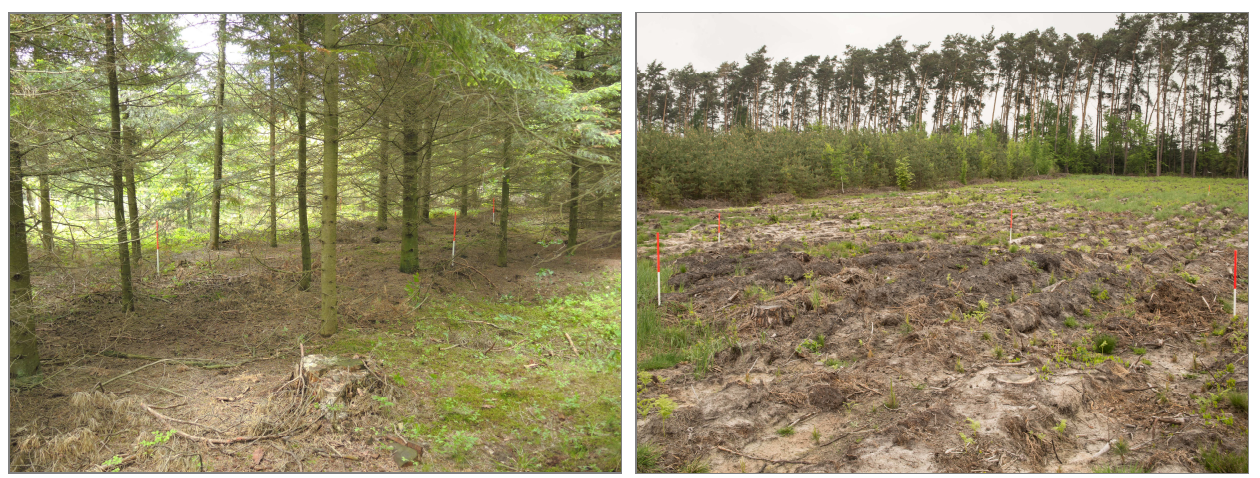

Ryc. 3. Pozostałości mielerzy zinwentaryzowane w czasie archeologicznych pomiarów terenowych (fot. R. Zapłata)

Fig. 3. The remains of a charcoal pile inventoried during archaeological field measurements (photo R. Zapłata)

\section{EKSPERYMENT}

W ramach zaplanowanych badań przeprowadzono eksperyment, w którym wykorzystano próbkę danych z lotniczego skanowania, służącą do wytworzenia numerycznego modelu terenu dla badanego obszaru, i na kolejnym etapie prac dokonano jego przetworzenia. W eksperymencie zasadniczą rolę odegrało stworzenie metodyki umożliwiającej automatyczne wskazanie konkretnych, wykrytych wcześniej obiektów o ustalonym położeniu, jak również wskazanie potencjalnych i niewykrytych dotychczas obiektów zabytkowych. Podczas prowadzonych prac, w celu dokonania porównań i oceny skuteczności proponowanego rozwiązania, zastosowano rezultaty badań związanych z dotychczasową detekcją obiektów zabytkowych, która oparta była przede wszystkim na prospekcji powierzchniowej oraz pomiarach lotniczego skanowania laserowego, wygenerowanym NMT i analizie danych z wykorzystaniem techniki modeli cieniowanych - cieniowania wielokierunkowego, rozdziel- 
nego (nie tworząc łącznych kompozycji z poszczególnych modeli). Tym samym zaplanowany eksperyment jest kolejnym etapem prac na rzecz opracowania metodyki nieinwazyjnego rozpoznawania i inwentaryzacji obiektów zabytkowych (archeologicznych), który poprzedziły prace terenowe i archiwalne, a także wstępne analizy na podstawie narzędzi geoinformatycznych. Pierwsze etapy prac bazowały na wyżej wspomnianej analizie danych dzięki funkcji cieniowania zboczy, a następnie na włączeniu do badań analizy głównych składowych (ang. principal component

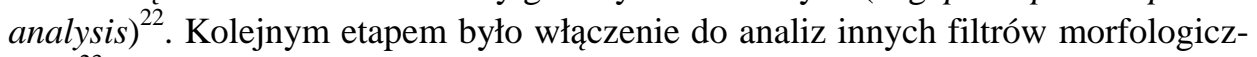
nych $^{23}$ (omawianych przekrojowo w tekście), a także wypracowanie i zastosowanie automatyzacji w procesie detekcji na podstawie narzędzi geoinformatycznych.

\section{Wykorzystane dane}

Prace oparto na numerycznych modelach terenu, uzyskanych z chmur punktów zarejestrowanych w ramach zlecenia wykonywanego przez MGGP Aero Sp. z o.o. skanerem Riegl model LMS-Q680i, wykorzystującym pomiar fali ciągłej (full-wave form), która wiosną 2012 r. wykonała nalot obszaru o całkowitej powierzchni $60 \mathrm{~km}^{2}$ w okolicy miejscowości Iłża, Seredzice i Pakosław, dokonując w następnej kolejności przetworzenia chmury punktów. Rezultatem końcowym prac były dane w postaci sklasyfikowanej chmury punktów, a także wygenerowane produkty pochodne - NMT oraz NMPT. Dane te charakteryzowały się średnią gęstością próbkowania -6 punktów na $\mathrm{m}^{2}$ dla całej chmury oraz 1 punkt na $\mathrm{m}^{2}$ dla klasy gruntu. Deklarowana dokładność wysokościowa punktów oszacowana została na $\mathrm{m}_{\mathrm{Z}} \leq 0,15 \mathrm{~m}$.

Obszar testowy na potrzeby przeprowadzenia eksperymentu miał powierzchnię $4 \mathrm{~km}^{2}$, dla którego wygenerowano nowy NMT, wytworzony poprzez triangulację punktów zawartych w klasie grunt, a następnie przepróbowano go do siatki GRID o rozdzielczości $0,5 \mathrm{~m}$ (ryc. 4). Za wykorzystaniem regularnej struktury NMT przemawia fakt, że taka struktura umożliwia przetwarzanie NMT w postaci rastrów w procesie detekcji metodami związanymi z przetwarzaniem obrazów. Dobór odpowiednich parametrów siatki GRID powinien być dostosowany zarówno do gęstości chmury punktów, jak i do wielkości oraz specyfiki wyszukiwanych obiektów, co pozwala zachować pożądane dokładności. Również ze względu na specyfikę wyszukiwanych obiektów (lokalne deniwelacje) oraz ich wielkość zdecydowano się na wspomnianą rozdzielczość rastra.

Przetworzenie geodanych oraz automatyczną detekcję poprzedziły prace dotyczące oceny jakości wykonanych pomiarów lotniczych, a zwłaszcza określenia gęstości punktów pomiarowych rejestrujących powierzchnię terenu.

\footnotetext{
${ }^{22}$ Zapłata, Borowski 2013.

${ }^{23}$ Kupidura, Koza, Marciniak 2010.
} 
a)

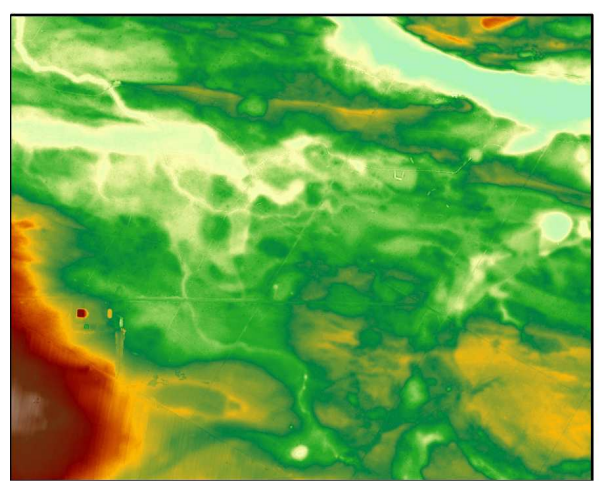

b)

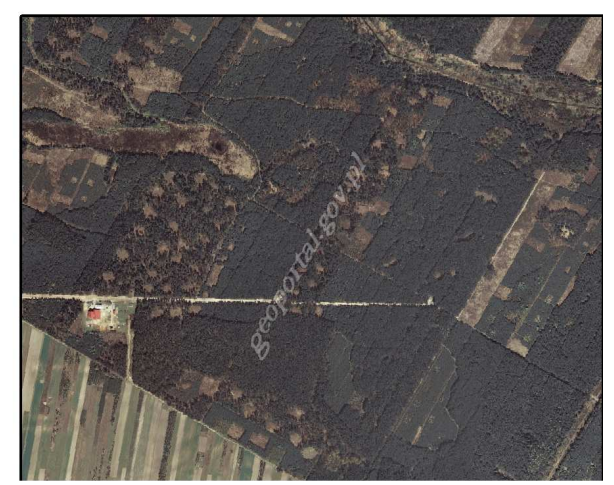

Ryc. 4. Analizowany obszar - (a) numeryczny model terenu (źródło: UKSW), (b) ortofotomapa (źródło: geoportal.gov.pl)

Fig. 4. The analyzed area - (a) digital terrain model (source: UKSW), (b) ortophotomap (source: geoportal.gov.pl)

\section{Automatyzacja w procesie detekcji obiektów}

Celem zastosowania automatyzacji w procesie detekcji jest wspomaganie działań w wyszukiwaniu, analizie, a także weryfikacji zasobów zabytkowych, opartych na interpretacji przetworzonych danych przestrzennych. Omawiana metoda jest szczególnie użyteczna wówczas, gdy na danym terenie, który podlega prospekcji, znajduje się dużo podobnych obiektów, takich jak np. kurhany czy mielerze. Automatyzacja w detekcji jest stosowana do lokalizacji zarysów konkretnych obiektów czy też ich pozostałości. Nie należy więc mylić z automatyzacją przetworzeń, których efektem jest wygenerowanie produktu pochodnego od NMT, służących wyeksponowaniu informacji zawartych w NMT dla całego obszaru. Rozważając wyniki automatyzacji w procesie detekcji i oceniając jej skuteczność, należy brać pod uwagę poprawność detekcji - zgodność ze stanem rzeczywistym (ile znalezionych określonym algorytmem obiektów jest nimi w rzeczywistości) oraz kompletność detekcji (ile obiektów z grupy wszystkich wykrytych zostało znalezionych właściwie). Poprawność jest weryfikowana przez odniesienie się do rezultatów innych badań i analiz, włącznie z prospekcją terenową. Natomiast kompletność detekcji jest określana poprzez odniesienie się do zespołu znanych i zlokalizowanych obiektów zabytkowych, a nie do wszystkich obiektów występujących w rzeczywistości.

W badaniach zdecydowano się na wykorzystanie techniki LRM (ang. Local Relief Model), uznawanej za jedną z najlepszych w poszukiwaniach obiektów $\operatorname{archeologicznych}^{24}$. Do stworzenia rastra LRM wykorzystano maskę filtracji dolno-

\footnotetext{
${ }^{24}$ Štular, Kokalj, Oštir, Nuninger 2012.
} 


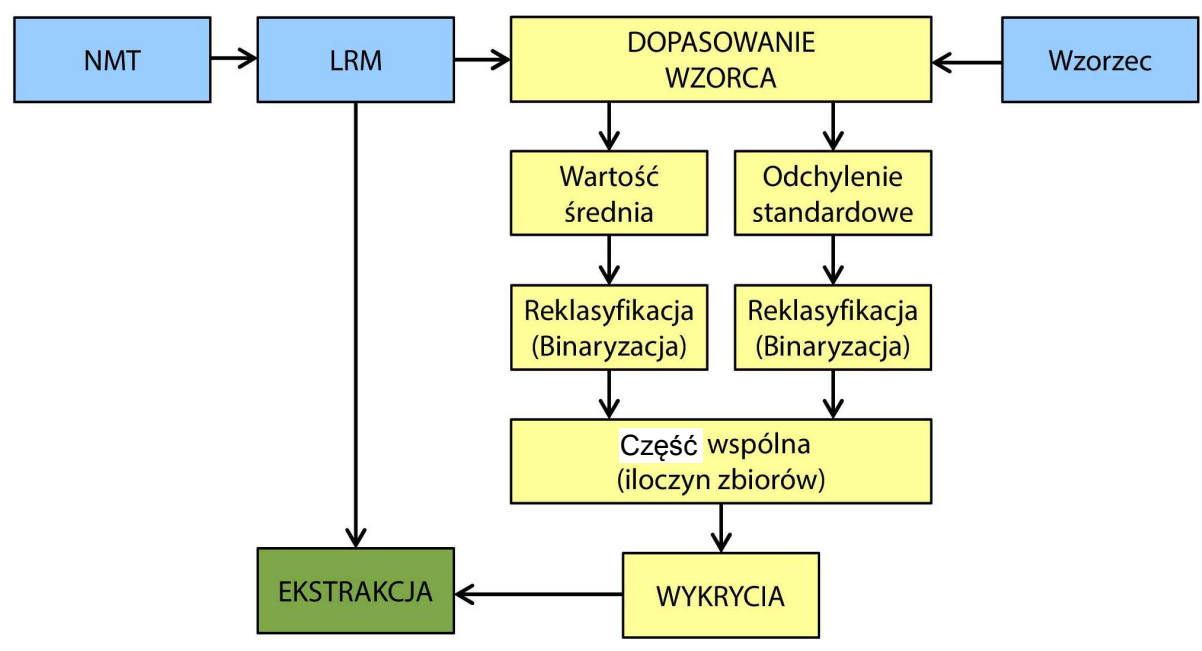

Ryc. 5. Ogólny schemat procesu detekcji obiektów archeologicznych w prezentowanych badaniach

Fig. 5. General scheme of the detection process of archaeological objects in the presented research

przepustowej o promieniu $3 \mathrm{~m}$, co umożliwiło analizę sąsiedztwa każdej komórki NMT. W procesie detekcji obiektu wykorzystano, podobnie jak w pracy Triera et al. ${ }^{25}$, wyszukiwanie wzorców (ang. template matching), polegające na zastosowaniu filtracji maską o żądanym kształcie i wielkości, w celu wytworzenia rastra wtórnego, ukazującego wartość średnią i odchylenie standardowe dla każdej komórki. Schemat całości metodyki detekcji przedstawiony został na rycinie 5 .

W eksperymencie, po przeprowadzeniu analizy znanych w terenie obiektów, przyjęto maskę, składającą się z dwóch kształtów: okręgu o promieniu $12 \mathrm{~m}$ oraz pierścienia o promieniu wewnętrznym $12 \mathrm{~m}$ i zewnętrznym $15 \mathrm{~m}$. Współczynniki wagowe filtrów wynosiły 0,15 dla wartości LRM położonych wewnątrz okręgu i -0,3 dla wartości LRM wewnątrz pierścienia. Za tak określonym kształtem maski przemawiał fakt istnienia dookolnych zgłębień, które wskazywać mogły punkt centralny, znajdujących się właśnie w odległości kilkunastu metrów od środka okrągłych obiektów. Po znormalizowaniu wartości średniej i odchylenia standardowego dobrano wartości progowe na podstawie analizy tych rastrów dla obszarów przykładowych mielerzy pomierzonych w terenie, ustalono granicę wartości średniej na 0,53, a próg odchylenia standardowego na 0,06 . Dla tak powstałych rastrów wyznaczono część wspólną zbiorów, odpowiadającą miejscom, w których potencjalnie znajdować mogły się poszukiwane obiekty. Otrzymana w wyniku zamiany pliku rastrowego na plik punktowy lista obiektów została poddana dodatkowo filtracji, związanej z występowaniem na niektórych obszarach niewystarczającej gęstości danych do stworzenia

\footnotetext{
${ }^{25}$ Trier, Zortea, Larsen 2012.
} 


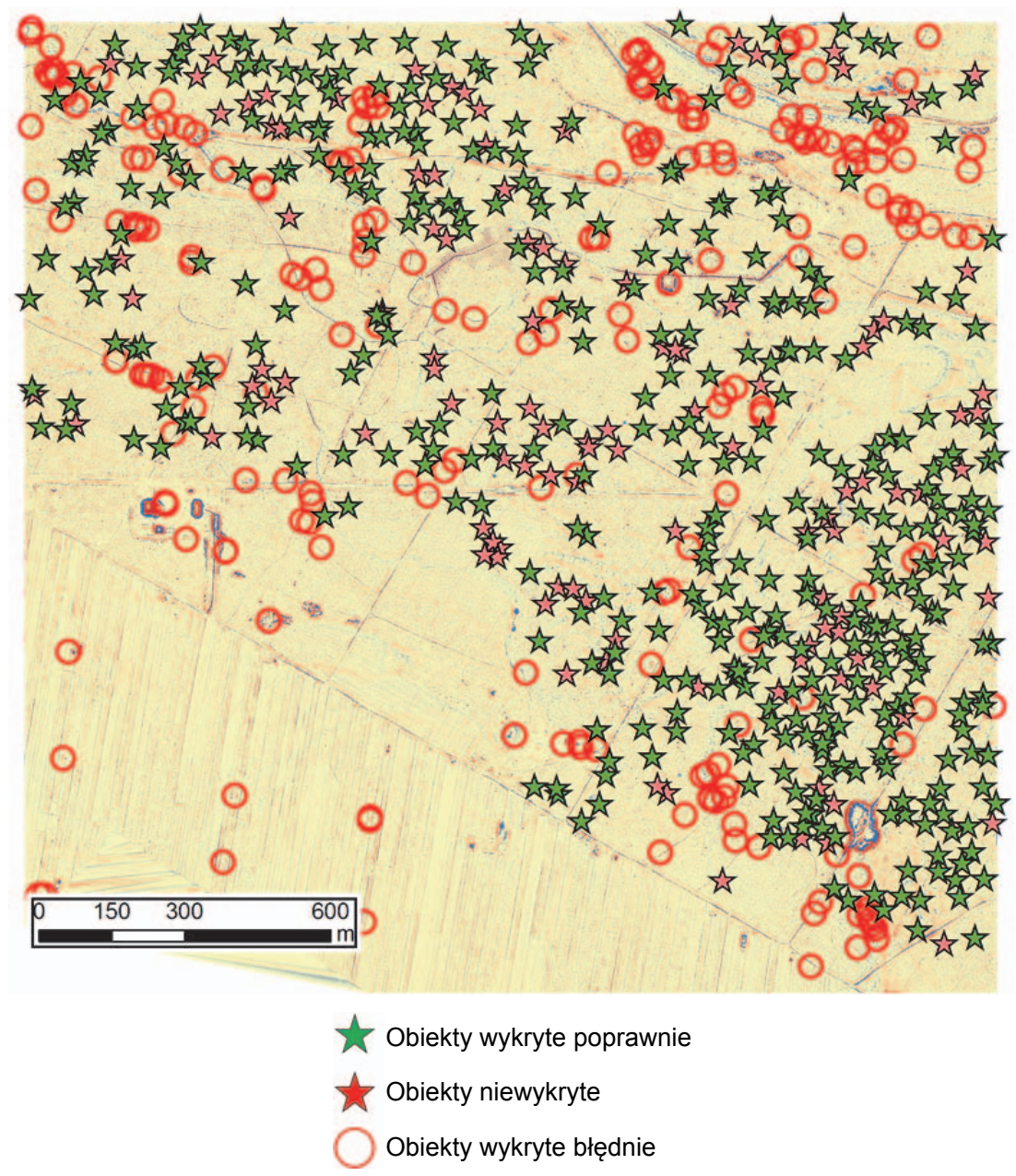

Ryc. 6. Wstępne wyniki detekcji obiektów archeologicznych z wykorzystaniem przedstawionej metodyki

Fig. 6. Preliminary results of the detection of archaeological objects using the outlined methodology

NMT, a uzyskane wyniki na tym terenie mogły być przypadkowe. Innymi przyczynami eliminacji niektórych lokalizowanych obiektów było ich położenie np. na skarpach dróg oraz zbyt mała odległość pomiędzy wykrytymi punktami.

\section{Wstępne rezultaty}

Uzyskane rezultaty przeprowadzonego eksperymentu przedstawione zostały graficznie na rycinie 6, na której na tle rastra LRM pokazano obiekty wykryte poprawnie, błędnie oraz obiekty niewykryte, a znane z wcześniejszych badań. Dane 
te posłużyły do obliczenia wartości liczbowych związanych z kompletnością i poprawnością detekcji (tab. 1). Tabela ta zawiera informacje dla 3 wariantów: pierwszy z nich (bez filtracji) dotyczy wykrytych wszystkich obiektów, drugi obiektów po eliminacji tych znajdujących się w odległości $6 \mathrm{~m}$ od osi dróg (stanowiących najczęściej skarpy), oraz trzeci - obiektów po eliminacji tych powstałych w miejscach, w których wysokość NMT wyznaczona była z dużą dozą niepewności w związku z małą gęstością danych.

Tabela 1. Statystyki wstępnych rezultatów detekcji

Table 1. Preliminary results of detection

\begin{tabular}{|l|c|c|c|c|c|c|}
\hline \multicolumn{1}{|c|}{ Wariant } & $\begin{array}{c}\text { Obiekty refe- } \\
\text { rencyjne- } \\
\text { obiekty znane }\end{array}$ & $\begin{array}{c}\text { Obiekty wy- } \\
\text { kryte na pod- } \\
\text { stawie auto- } \\
\text { matycznej } \\
\text { detekcji }\end{array}$ & $\begin{array}{c}\text { Obiekty nie- } \\
\text { wykryte na } \\
\text { podstawie } \\
\text { automatycznej } \\
\text { detekcji }\end{array}$ & $\begin{array}{c}\text { Obiekty błęd- } \\
\text { nie wykryte na } \\
\text { podstawie } \\
\text { automatycznej } \\
\text { detekcji }\end{array}$ & $\begin{array}{c}\text { Poprawność } \\
\text { automatycznej } \\
\text { detekcji }\end{array}$ & $\begin{array}{c}\text { Kompletność } \\
\text { automatycznej } \\
\text { detekcji }\end{array}$ \\
\hline $\begin{array}{l}\text { Wynik automa- } \\
\text { tycznej detekcji } \\
\text { bez filtracji }\end{array}$ & 515 & 396 & 119 & 610 & $39 \%$ & $77 \%$ \\
\hline $\begin{array}{l}\text { Wynik automa- } \\
\text { tycznej detekcji } \\
\text { bez obiektów przy } \\
\text { drogach }\end{array}$ & 508 & 391 & 117 & 234 & $63 \%$ & $77 \%$ \\
\hline $\begin{array}{l}\text { Wynik automa- } \\
\text { tycznej detekcji } \\
\text { bez obiektów przy } \\
\text { małej gęstości } \\
\text { punktów }\end{array}$ & 498 & 381 & 117 & 178 & $68 \%$ & $77 \%$ \\
\hline
\end{tabular}

\section{DYSKUSJA}

Zawarte w tabeli wyniki ukazują wykrycie $77 \%$ obiektów, których położenie zostało określone $\mathrm{w}$ pomiarze terenowym bądź przez manualny pomiar na rastrze LRM. To ten parametr decyduje głównie o usprawnieniu żmudnego, manualnego poszukiwania obiektów w pracach kameralnych, wskazując miejsca, w których należy dokonać dalszej analizy i weryfikacji. Kluczowym parametrem, stanowiącym zasadniczy argument na rzecz stosowania automatycznej detekcji, jest kompletność, która, jak pokazują publikacje, może sięgać $94 \%{ }^{26}$. Jest to oczywiście wartość dotycząca innego typu obiektów i nie może być ona odnośnikiem dla przeprowadzonych badań. Warto jednak zwrócić także uwagę, że badania nie uwzględniały różnorod-

\footnotetext{
${ }^{26}$ Trier, Zortea, Larsen 2012.
} 
nych parametrów poszukiwawczych wzorca, do których należy zaliczyć: inne rozmiary wzorca, analizy w różnych kierunkach czy ewentualnie większej liczby parametrów analizy rastra powstałego w wyniku wykrycia dopasowaniem wzorca. Takie działanie mogłoby podnieść współczynnik kompletności, a tym samym efektywność stosowanej procedury. Przedstawiona metodyka była jedynie próbą wykorzystania takiego podejścia w odniesieniu do obiektów archeologicznych, jakimi są mielerze. Efekt tego działania można uznać za pozytywny, co dobrze rokuje przyszłym badaniom dotyczącym całości obszaru z okolic Iłży, jak również innych terenów, na których należy spodziewać się równie licznie występujących pozostałości zabytkowych mielerzy.

Stosowanie automatyzacji w procesie detekcji jest bardzo istotne nie tylko ze względu na szansę dodatkowej weryfikacji rezultatów wcześniejszych badań, lecz także z uwagi na możliwość detekcji potencjalnych - nowych obiektów. Duża liczba obiektów na tak małej powierzchni powoduje, że zakres prac wykonywanych np. manualnie na większych obszarach mógłby być bardzo czasochłonny. Dodatkową zaletą automatyzacji jest możliwość generowania map ilustrujących położenie obiektów zabytkowych, ich zarysów czy też przekształcania ich rastrowej prezentacji na rysunek wektorowy (ryc. 7).
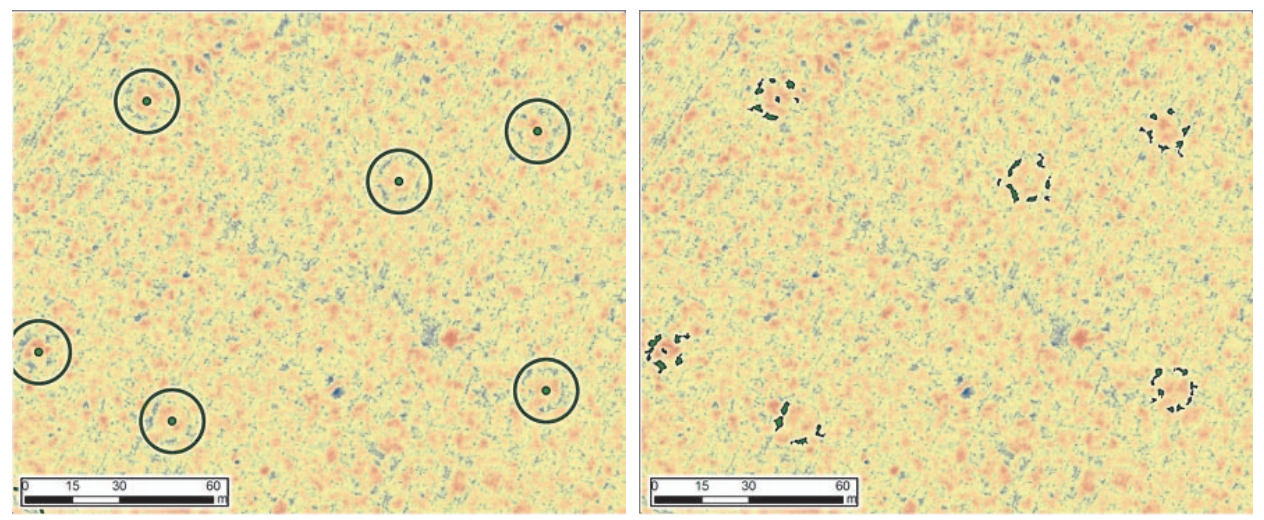

Rys. 7. Możliwości prezentacji wyników detekcji dla tworzenia dokumentacji zabytków archeologicznych

Fig. 7. Possibilities of results presentation for creation of archaeological monuments documentation

\section{WNIOSKI I DALSZE PRACE}

Przedstawione badania udowodniły, że dane ALS szczególnie dla terenów zalesionych są najlepszym źródłem danych w detekcji zasobów archeologicznych. Zróżnicowane przetwarzanie geodanych, a następnie rozpoznawanie obiektów zabytko- 
wych jest również możliwe z wykorzystaniem automatycznych procedur, znacząco przyspieszających i wspierających analizy wielkoobszarowe. Przede wszystkim wyniki przeprowadzonego eksperymentu dowodzą, że taka forma detekcji może znacząco poprawić wydajność i efektywność prac w krótkim czasie. Wyniki poprawności detekcji na podstawie zastosowanego algorytmu potwierdzają konieczność przeprowadzania kontroli kameralnej, a szczególnie terenowej, która pozwoli na weryfikację uzyskanych rezultatów. Automatyczną detekcję obiektów archeologicznych należy zatem potraktować jako podejście wspierające i komplementarne wobec innych metod.

Przyszłe prace będą dotyczyć optymalizacji doboru parametrów wyszukiwania obiektów, z uwzględnieniem różnorodności występujących na tym obszarze zabytków. Opracowana metodyka detekcji zastosowana będzie w odniesieniu do całości badanego zespołu zabytkowych mielerzy, dla którego uzyskano dane z lotniczego skanowania laserowego. Badania te mogą udowodnić istnienie jednego z największych tego typu kompleksów obiektów w Polsce czy Europie, przyczyniając się również do jego inwentaryzacji i ochrony.

\section{BIBLIOGRAFIA}

Bartosik J.

1979 Iłża. Monografia rozwoju społeczno-gospodarczego miasta, Biuletyn Kwartalny Radomskiego Towarzystwa Naukowego 16/3, s. 31, 42-43.

Bennett R., Welham K., Hill R., Ford A.

2012 A comparison of visualization techniques for models created from airborne laser scanned data, Archaeological Prospection 19, s. 41-48.

Bewley R.H., Crutchley S., Shell C.A.

2005 New light on an ancient landscape: lidar survey in the Stonehenge World Heritage Site, Antiquity 79 (305), s. 636-647.

Będkowski K., Wężyk P.

2010 Lotniczy skaning laserowy [w:] Geomatyka w Lasach Państwowych, cz. I: Podstawy, red. K. Okła, Warszawa, s. 326-343.

Bielenin K.

1959 Starożytne mielerze świętokrzyskie hutnictwa żelaza, Kwartalnik Historii Kultury Materialnej, R. VII, s. 463-472.

Chase A.F., Chase D.Z., Weishampel J.F., Drake J.B., Shrestha R.L., Slatton K.C., Awe J.J., Carter W.E. 2011 Airborne LiDAR, archaeology, and the ancient Maya landscape at Caracol, Belize, Journal of Archaeological Science 38/2, s. 387-398.

http://www.caracol.org/include/files/chase/JASarticle.pdf. [dostęp: 02.05.2013].

Devereux B., Amable G., Crow P.

2008 Visualisation of lidar terrain models for archaeological feature detection, Antiquity 82 (316), s. 470-479. 
Doneus M., Briese C.

2006 Full-waveform airborne laser scanning as a tool for archaeological reconnaissance [w:] From Space to Place 2. International Conferenceon Remote Sensing in Archaeology, red. S. Campana, M. Forte, BAR International Series 1568, Oxford, s. 99-106.

Dunin A.

1828 Wykład praktyczny węglarstwa stosowego. O różnych sposobach węglenia, Sylwan 5, s. 238-300.

Guldon Z.

2001 Staropolski Okręg Przemysłowy [w:] Staropolski Okręg Przemystowy, red. P. Pierściński, Kielce, s. 32-35.

Guldon Z., Kaczor J.

1994 Górnictwo i hutnictwo w Staropolskim Okręgu Przemystowym w drugiej połowie XVIII wieku, Kielce.

Hesse R.

2010 Lidar-derived local relief models - a new tool for archaeological prospection, Archaeological Prospection 17, s. 67-72.

Kałagate S., Osypiński P., Stachowiak P.

2012 Relikty późnonowożytnego mielerza odkryte na stanowisku nr 4 w Wilkowie, gm. Świdnica, pow. zielonogórski, woj. lubuskie, Archeologia Środkowego Nadodrza 9, s. 241-249.

Kokalj Ž., Zakšek K., Oštir K.

2013 Visualizations of lidar derived relief models [w:] Interpreting archaeological topography - airborne laser scanning, aerial photographs and ground observation, red. R.S. Opitz, D.C. Cowley, Oxford, s. 100-114.

Kupidura P., Koza P., Marciniak J.

2010 Morfologia matematyczna w teledetekcji, Warszawa.

Kurczyński Z.

$2006 \quad$ Lotnicze i satelitarne obrazowanie ziemi, Warszawa.

Ludemann T.

2011 Scanning the historical and scientific significance of charcoal production - local scale, high resolution kiln site anthracology at the landscape level, SAGVNTVM extra 11, s. $23-24$.

http://ojs.uv.es/index.php/saguntumextra/article/view/1546/920 [dostęp: 02.05.2013].

Łabęcki H.

1841 Górnictwo w Polsce. Opis kopalnictwa i hutnictwa polskiego, pod względem technicznym, historyczno-statystycznym i prawnym, Warszawa, t. 2, s. 54.

Łoboda L.

2001 Staropolski Okręg Przemysłowy w XVI-XVII wieku [w:] Region świętokrzyski. Mit czy rzeczywistość?, red. J. Wijaczka, Kielce, s. 159-180.

Pazdur J.

1962a Przemysł zbrojeniowy Zagłębia Staropolskiego do połowy XIX wieku, Rocznik Świętokrzyski, t. I., Wrocław.

1962b Staropolskie Zagłębie Przemysłowe, Rocznik Świętokrzyski, t. I, Wrocław.

Possel B., Lindenbergh R., Storms J.

2010 Automatic detection of buried channel deposits from dense laser altimetry data, International Archives of the Photogrammetry, Remote Sensing and Spatial Information Sciences 38/7A, s. 192-197. 
Rösler H., Bönisch E., Schopper F., Raab T., Raab A.

2012 Pre-industrial charcoal production in southern Brandenburg and its impact on the environment [w:] Landscape Archaeology between Art and Science, red. S. Kluiving, E. Guttmann-Bond, Amsterdam, s. 167-178.

Štular B., Kokalj Z., Oštir K., Nuninger L.

2012 Visualization of lidar-derived relief models for detection of archaeological features, Journal of Archaeological Science 39, s. 3354-3360.

Trier Ø.D., Zortea M., Larsen S.Ø.

2012 Semi-automatic detection of burial mounds in forested areas [w:] European Association of Remote Sensing Laboratories. 32nd EARSeL Symposium Proceedings Advances in Geosciences. Mykonos Island, Greece, 21 May - 24 May 2012, red. K.G. Perakis,

Weiss A. A.K. Moysiadis, Wolos, s. 113-124.

2001 Topographic position and landforms analysis.

URL:http://www.jennessent.com/downloads/tpi-poster-tnc_18x22.pdf [dostęp: czerwiec 2013]

Wężyk P.

2006 Wprowadzenie do technologii skanowania laserowego w leśnictwie, Rocznik Geomatyki 4/4, s. 119-132.

Zapłata R.

2013 Sprawozdanie czastkowe z badań nieinwazyjnych przeprowadzonych $w$ III/IV kwartale 2012 r. oraz I kwartale 2013 r. na terenie Leśnictwa Seredzice oraz Polany (część S). Projekt naukowy pt. „Zastosowanie skaningu laserowego oraz teledetekcji w ochronie, badaniu $i$ inwentaryzacji dziedzictwa kulturowego. Opracowanie nieinwazyjnych, cyfrowych metod dokumentacji i rozpoznawania zasobów dziedzictwa architektonicznego $i$ archeologicznego", [maszynopis w archiwum UKSW oraz WMKZ - Radom], Warszawa.

Zapłata R., Borowski M.

2013 GIS w archeologii - przykład prospekcji i inwentaryzacji dziedzictwa archeologiczno-przemysłowego, Rocznik Geomatyki, s. 103-112.

Zieliński J.

1965 Staropolskie Zagłębie Przemystowe, Wrocław.

Zientara B.

1954 Dzieje małopolskiego hutnictwa żelaznego - XIV-XVII wiek, Warszawa.

Prace naukowe finansowane w ramach programu Ministra Nauki i Szkolnictwa Wyższego pod nazwą „Narodowy Program Rozwoju Humanistyki” w latach 2012-2015. 


\section{AUTOMATION IN THE PROCESS OF ARCHAEOLOGICAL OBJECTS DETECTION FROM ALS DATA}

\section{S u m m a r y}

In this paper approaches of historical, archaeological objects detection from airborne laser scanning data were shown. Surrounding of the castle in Iłża with immovable monuments, identified as the industrial heritage, were the test study of this research. Presented approach of automatic extraction of charcoal pile was the analysis of the selected processing of digital terrain model. Hillshade models, composition of different hillshade models and their principal components as well as TPI and LRM rasters have been analyzed in this case. As the best product of DTM processing to expose characteristics in DTM, the LRM raster was selected as an input for automatic detection procedure. Subsequently, it was attempted to detect archaeological sites on a small test area by usage of template matching. Positive results proved a great number of detected objects over $77 \%$ of objects measured indirectly were detected in proposed methodology (completeness). This approach represents correctness result of $68 \%$ which means that $32 \%$ of detected points have appeared to be not real objects of interest. Presented approach was assessed by the results of object extraction in respect to the field measurements in the area of interest, as well as effectiveness of automation procedure. This study proved that the ALS, especially of woodland, seems the best source of information to produce reliable archaeological documentation. 